\title{
PLANTS USED AS FENCE AND FUELWOOD IN MANANG DISTRICT, CENTRAL NEPAL
}

\author{
S. Bhattarai*, R. P. Chaudhary* and R. S. L. Taylor** \\ *Central Department of Botany, Tribhuvan University, Kirtipur, Kathmandu, Nepal. \\ **Community Medicine, McGill University, Montreal, QC, Canada.
}

\begin{abstract}
The remoteness of Manang District, Central Nepal has resulted in continued use of wild plants to meet daily needs. Local people were interviewed during 2002-2006 regarding the uses of plants as sources of fence and fuelwood. The People of Manang have been using 16 plant species (eight trees and eight shrubs) which belong to nine families and 10 genera for fence and fuelwood. The highest number of species belonged to Berberidaceae (4 species), followed by Cupressaceae (3 species), Rosaceae and Pinaceae (2 species each). Taxaceae, Elaeagnaceae, Betulaceae, Salicaceae and Juglandaceae were represented by one species each. Among 16 species recorded, eleven species including Berberis lycium, Hippophae salicifolia, Juniperus indica, Rosa macrophylla, etc., were used as fence and 11 species including Betula utilis, Juniperus indica, Pinus wallichiana, etc., were used as a source of fuelwood. Some plants are used as both fence and fuelwood. Fence plants protect crop field from damage by livestock and wild animals and prevented soil erosion by wind. The local people of TankiManang, Manang, Braka, Munji do not collect fuelwood, and furniture wood from their nearby forest these days as they did in the past and now collect from the next village (Hongde and Pisang forest). This a good example of awareness towards conservation and forest management. The forests near their villages are now named as 'community forest'. There is a continued need for awareness among the people about forest use and its role in the environment.
\end{abstract}

Key words: Awareness; Community forest; Livestock; Manang; Wild plants.

\section{INTRODUCTION}

The district of Manang (2000-6000m above mean sea level (amsl)) is located in the north central Himalayas, Nepal. People of Tibetan and Gurung origin live in the area (Spengen, 1987). The Trans-Himalaya region of north-central Nepal is a cold, dry, wind-swept area of high mountains and isolated valleys located between the crest of the Great Himalaya mountain range and the Tibetan Marginal mountain range. Besides the differences in relief and geology, climate and ecological conditions change as well and emphasize the division of the district area into three ecological regions: Gyasumdo in the southeast, Nyeshang in the west and Nar/Phoo in the north (Pohle, 1988; Rogers, 2004).

This paper presents field observations regarding on the traditional applications of the plants (fuel wood and fence) used by the people of the Manang district, Nepal. Manang is one of the least explored districts in the field of ethnobotany, especially in comparison to other districts of Nepal. Most of the work in Nepal has been conducted in the field of medicinal plants followed by general ethnobotany, mainly focusing on the uses of plants in Nepal (Bhandari and Shrestha, 1982; Chaudhary, 1998; Chhetri, 2005; HMG/N, 1982; Manandhar, 1989, 2002; Mueller-Boker, 1999; Toba, 1975), although only few studies (Manandhar, 1987; Pohle, 1990; Bhattarai et al., 2006a, 2006b; Bhattarai and Chaudhary, 2006) have documented the traditional knowledge of plants in Manang district. The specific geographical feature of Manang combined with a lack of modern facilities resulted in continued reliance on indigenous knowledge for the fulfilment of their daily needs.

\section{MATERIALS AND METHODS}

The present study was undertaken in and around the villages of Manang district i.e., Chame, Bhratang, Dhukurpokhari, Pisang, Hongde, Munji, Ghyaru, Ngawal, Braga, Manang, TankiManang, Khangshar, Nar, Phoo; and places such as Tilicholake, Kacholake, Yakshed, and Goatshed. Ten field visits were made, during the years 2002-2006 for the collection of ethnobotanical information. The information was gathered by direct field observations and interviewing knowledgeable villagers. Herbarium specimens were collected and identified by two of us (S.B. and R.P.C.) with the help of standard literature (Polunin and Stainton, 1984; Stainton, 1988; Grierson and Long, 1983-2000), and nomenclature of the identified species follows (Hara and Williams, 1979; Hara et al., 1982, 1978), and Press et al., 2000. A set of voucher herbarium specimens was made for each collection, and the voucher numbers are listed below. These vouchers have been deposited in the Tribhuvan University Central Herbarium (TUCH), Nepal.

Author for Correspondence: R. P. Chaudhary, Central Department of Botany, Tribhuvan University, Kirtipur, Kathmandu, Nepal. 


\section{RESULTS}

A categorical list of plant species along with their scientific name (arranged alphabetically), family name (in capital letters), voucher number, Local names (Gurung), taxonomic description, distribution, and usage are given below. The present study recorded 16 plant species belonging to nine families under10 genera which are being used as fence and fuelwood in Manang. Among these plants eight are trees and the remaining eight are shrubs. Of nine families recorded Berberidaceae consists of highest number (4 species), followed by Cupressaceae (3 species), Rosaceae and Pinaceae (2 species each). Five families Taxaceae, Elaeagnaceae, Betulaceae, Salicaceae, and Juglandaceae were represented by one plant species each.

Among 16 plant species, twelve species were used as a source of fence. Similarly, 11 plant species were used as fuelwood (see Table 1). Approximately $95 \%$ of the recorded plant species also have important medicinal usage in Manang (Bhattarai et al., 2006a) but this paper deals only with their uses as fence and fuelwood. The common parts of the plants used for fence and fuelwood are stems, and branches. Eight plant species Berberis angulosa, Berberis aristata, Berberis ceratophylla, Berberis lycium, Hippophae salicifolia, Rosa macrophylla, Rosa sericea and Salix wallichiana were used as living fence. Ten plant species Berberis angulosa, Berberis aristata, Berberis ceratophylla, Berberis lycium, Juniperus communis, Juniperus indica, Juniperus squamata, Rosa macrophylla, Rosa sericea and Salix wallichiana were used as fence after harvesting.

\section{TAXONOMIC DESCRIPTION AND USAGE}

1. Abies spectabilis (D. Don) Mirb. (PINACEAE), Voucher 342. Kye (Gurung).

Pyramidal tree ca. 50 m, upper branches horizontal. Bark dark grey, deeply grooved. Leaves sessile linear, base round, margin entire and incurved, apex rounded and notched. Young branchlets with hairy grooves. Cones erect, Male cones smaller; Female cones dark purple. Distribution: Nepal (WC, 2400-4000 m), Himalaya (Kashmir to Nepal), Pakistan (Chitral). Usage: Stem as fuel wood.

2. Berberis angulosa Wall. ex Hook. f. \& Thomson (BERBERIDACEAE), Voucher 444. Kyunudzu (Gurung).

Shrub ca. 1-15 m, deciduous. Stems brownish, strongly grooved, minutely pubescent. Spines 3-fid, internodes usually short ca. $1 \mathrm{~cm}$. Leaves herbaceous, elliptic-obovate, base attenuate, margin spinous, apex acute. Flower solitary; outer sepals ovate; inner broader. Petals obovate. Fruit ellipsoid. Distribution: Nepal (CE, 3400-4500 m), Himalaya (Nepal to Sikkim), NE India, China. Usage: Due to its thorny nature, the whole plant is used to fence in fields by spreading the harvested shrubs it over a stone or wood wall.

3. Berberis aristata DC. (BERBERIDACEAE), Voucher 498. Karya (Gurung).

Shrub ca. 1-3 m, deciduous. Stems brownish, grooved, spines
1-2 cm. Leaves obovate, base attenuate, margin with spines. Sepals increasing gradually in size; outermost ovate, inner obovate. Petals obovate, with distinct unbranched veins. Berries narrowly ellipsoid. Distribution: Nepal (WCE, 1800$3500 \mathrm{~m}$ ), Himalaya (Nepal to Bhutan), India. Usage: Due to its thorny nature, the whole plant is used to fence in fields by spreading the harvested shrubs it over a stone or wood wall.

4. Berberis ceratophylla G. Don (BERBERIDACEAE), Voucher 353. Kyerpa (Gurung).

Shrub ca. $2 \mathrm{~m}$, conspicuously grooved pale yellow-grey stems, and fairly short stem. Leaves with numerous marginal spines, oblanceolate to wedge-shaped. Flowers yellow, in many flowered clusters which are branched below. Fruit very dark red or purple, oblong-ovoid. Distribution: Nepal (CE, 1800-4000 m), Himalaya (Nepal to Bhutan), Myanmar. Usage: Due to its thorny nature, the whole plant is used to fence in fields by spreading the harvested shrubs it over a stone or wood wall.

5. Berberis lycium Royle (BERBERIDACEAE), Voucher 171. Matimru (Gurung).

Shrub 3-4 m. Stem hairless with narrow fine-pointed leathery lanceolate leaves mostly without spiny teeth, glaucous beneath. Flowers dull yellow, borne in axillary clusters, longer than the leaves. Fruit black. Distribution: Nepal (CE, 18002900 m), Himalaya (Kashmir to Nepal). Usage: Due to its thorny nature, the whole plant is used to fence in fields by spreading the harvested shrubs it over a stone or wood wall.

6. Betula utilis D. Don (BETULACEAE), Voucher 201. Buspath (Gurung).

Tree ca. 15 m. Bark pinkish; branches often warty glandular. Leaf blade ovate, base rounded, margins regularly serrate, apex acute, pubescent on veins and glandular beneath. Stipules ovate, elliptic, deciduous. Male catkins solitary, axillary. Female spikes with 1-3 ovaries at base. Fruit with scarious wings. Distribution: Nepal (WCE, 2700-4300 m), Himalaya, W. China. Usage: The plant is a good source of fuel wood and is said to give good burn in comparison to the others fuelwood in Manang. It is ranked first (fuelwood) by the local people in Manang.

\section{Hippophae salicifolia D. Don (ELAEAGNACEAE), Voucher 2246. Tarbu (Gurung).}

Deciduous thorny shrub or small tree, ca. $5 \mathrm{~m}$, with rusty scaly shoots. Leaves oblong-lanceolate, densely whitedowny beneath, with dense stalkless clusters of yellowishbrown male flowers, the female flowers solitary appearing on leafless stems. Stamens usually 4; stigma exserted. Fruit globular, orange or red. Distribution: Nepal (WC, 2200-3500 $\mathrm{m})$, Himalaya (Punjab to Bhutan), China (Xizang). Usage: It is used on the shores of rivers and in the fields as a fence that also helps to check soil erosion.

8. Juglans regia L. (JUGLANDACEAE), Voucher 2135. Katutun (Gurung).

Large deciduous tree with grey vertically fissured bark, 
distinguished by its pinnate leaves. Leaflets 5-13, elliptic to ovate pointed, entire, leathery. Male catkins pendulous, green; female flowers very small, in a short spike. Drupes green containing wrinkled nuts. Distribution: Nepal (WCE, 1200-2100 m), Himalaya (Kashmir to Bhutan), NE India (Meghalaya), China (Xizang). Usage: Occasionally it is also used as a source of fuelwood if there is a scarcity of other fuelwood.

\section{Juniperus communis L. (CUPRESSACEAE), Voucher 662. Phar (Gurung).}

Dense erect shrub, ca. $1.5 \mathrm{~m}$. Stems swollen below leaf insertion. Leaves spreading, needle like, 6-15 mm, with a broad bluish white band above, in whorls of 3 . Male cones tiny, ovoid. Fruit a fleshy blue-black berry, 3 seeded, ovoid, 6-8 mm. Distribution: Nepal (WC, 2700-3200 m), Arctic and Alpine region of $\mathrm{N}$. Hemisphere. Usage: Occasionally the stem is used as fuel wood at higher altitudes where there is a scarcity of other fuel occurred. It is also used as fencing in the crop fields.

\section{Juniperus indica Bertol. (CUPRESSACEAE), Voucher} 277. For (Gurung).

Tree, erect or procumbent, ca. $20 \mathrm{~m}$ high, with hard trunk, ultimate branchlets densely arranged. Leaves both scale like and needle like; needle like leaves usually present on young branches, apex acuminate; scale like leaves decussate, linear, apex obtuse. Fruit a fleshy berry, one seeded, 5-10 mm, brown then shining blue. Distribution: Nepal (WCE, 3700-4100 m), Karakoram, Himalaya, W. China. Usage: Stem as fuel wood. It is also used as fencing for crop fields.

11. Juniperus squamata Buch.-Ham. ex D. Don (CUPRESSACEAE), Voucher 265. Sukri (Gurung).

Dwarf spreading, prostrate shrub up to $1 \mathrm{~m}$; bark flaky brown, branchlets densely arranged, straight or recurved. Leaves in whorls of 3, spreading or ascending, straight or slightly covered, apex-acute or acuminate. Fruit a fleshy berry, reddishbrown to black, 1-seeded, seeds ovoid ridged. Distribution: Nepal (WCE, 3300-4400 m), Afghanistan, Himalaya, N. Myanmar, W. China. Usage: Stem is used as fuelwood in higher altitudes in the absence of other fuelwood. It is also used as fencing in the crop fields.

12. Pinus wallichiana A.B. Jacks. (PINACEAE), Voucher 276. Thansin (Gurung).

Tree ca. $70 \mathrm{~m}$ tall, trunk $1 \mathrm{~m}$ or more in breadth, young shoots greenish or weakly glaucous, glabrous. Leaves dark bluishgreen, $11-18 \mathrm{~cm}$, borne on thick shoots ca. $2 \mathrm{~mm}$, 5 per bundle, needle shaped; needles minutely toothed. Male cones 8-10 mm; Female cones $10-15$ cm when matured; scales oblong, obtuse ca. $2.5 \mathrm{~mm}$ broad. Distribution: Nepal (WCE, 18004100 m), Afghanistan, Himalaya (Kashmir to Nepal). Usage: Plant is used as fuelwood and is ranked third (first Betula utilis; second Juniperus indica and third Pinus wallichiana) by the local people among fuelwood species in Manang. Category of ranking is given by the local people according to good burn.
13. Rosa macrophylla Lindl. (ROSACEAE), Voucher 343. Seghu (Gurung).

Erect shrub ca. 1-5 m, stems often bearing paired straight prickles. Leaflets 7-11, ovate, acute, glabrous above. Flowers terminal on short lateral shoots. Calyx tube covered with bristles. Petals obovate, deep pink. Styles free, almost concealed by white hairs. Distribution: Nepal (WCE, 2100$3800 \mathrm{~m}$ ), Himalaya (Kashmir to Bhutan). Usage: Due to its thorny nature it is used as fencing and is also used as fuelwood in the higher altitudes where fuelwood is rare.

14. Rosa sericea Lindl. (ROSACEAE), Voucher 102. Sewa (Gurung).

Erect shrub up to $4 \mathrm{~m}$, stem bearing broad prickles. Leaflets 711 , base attenuate, margins usually serrate near apex, apex acute; Flowers solitary on short lateral shoots, 4-merous. Petals creamy white, broadly obovate. Styles free. Distribution: Nepal (WCE, 2200-4600 m), Himalaya (Chamba to Bhutan), Tibet, Assam, N. Burma, W. China. Usage: Due to its thorny nature it is used as fence and is also used as fuelwood in the higher altitudes where the fuel wood is rare.

15. Salix wallichiana Anderss. (SALICACEAE), Voucher 2015. Langmanackpo (Gurung).

Tree, 5-10 m, branchlets pubescent. Leaves elliptic 5.5-14 x 2$5 \mathrm{~cm}$, acute, base cuneate or rounded, entire or serrulate, sparsely pubescent above, greyish pubescent beneath; petioles $0.5-1.5 \mathrm{~cm}$. Catkins sessile or on peduncles ca. $1 \mathrm{~cm}$. Male catkins erect, $1.5-2.5 \mathrm{~cm}$, bracts oblong-lanceolate, 1 2.5 x 0.5-1 mm, white villous; stamens 2. Female catkins drooping, 7-15 x $1 \mathrm{~cm}$, bracts similar to male. Capsules narrowly ovoid, ca. $8 \mathrm{~mm}$, densely pubescent. Distribution: Nepal (WCE, 1500-3500 m), Afghanistan, Himalaya (Kashmir to Bhutan), Assam, Tibet, N. Burma, China. Usage: Stems are used as fuelwood when other fuelwood is scarce. The whole plant is also used as fencing.

16. Taxus wallichiana Zucc. (TAXACEAE), Voucher 2184. Silingi (Gurung).

Tree ca. $30 \mathrm{~m}$, but usually not more than $10 \mathrm{~m}$, with dark green foliage, and thin dark reddish-grey flaking bark. Leaves linear flattened, curved, spiny-tipped, leathery and dark glossy green, 2-ranked, borne on hairless branchlets. Fruit red fleshy, ca. $8 \mathrm{~mm}$, often almost concealing the single green seed. Distribution: Nepal (WCE, 2300-3400 m), Afghanistan, Himalaya (Kashmir to Bhutan), NE India, N. Myanmar, IndoChina, W. China, Malaysia. Usage: Stem is used as fuelwood.

\section{DISCUSSION}

Fence plants play an important role in Manang in preventing wild animals from entering crop fields. Plants species having spines, thorns, branching are mostly preferred for fencing. Some of these plants are grown around the field permanently as a 'living fence' whereas some are harvested and temporarily placed as a barrier. Manang district is very windy so this fencing helps to stop soil erosion and acts as a wind breakers. Out of the eleven plant species used for fences (see table 1) 
Table 1: Plants and their uses.

\begin{tabular}{|l|c|c|c|}
\hline \multicolumn{1}{|c|}{ Plant species } & Used as living fence & Harvested for fencing & Used as fuelwood \\
\hline Abies spectabilis & No & No & Yes \\
\hline Berberis angulosa & Yes & Yes & No \\
\hline Berberis aristata & Yes & Yes & No \\
\hline Berberis ceratophylla & Yes & Yes & No \\
\hline Berberis lycium & Yes & Yes & No \\
\hline Betula utilis & No & No & Yes \\
\hline Hippophae salicifolia & Yes & No & Yes \\
\hline Juglans regia & No & Yes & Yes \\
\hline Juniperus communis & No & Yes & Yes \\
\hline Juniperus indica & No & Yes & Yes \\
\hline Juniperus squamata & No & No & Yes \\
\hline Pinus wallichiana & No & Yes & Yes \\
\hline Rosa macrophylla, & Yes & Yes & Yes \\
\hline Rosa sericea, & Yes & Yes & Yes \\
\hline Salix wallichiana & Yes & No & No \\
\hline Taxus wallichiana & No & No & No \\
\hline
\end{tabular}

the species of Rosa and Berberis were most often grown around the crop field and harvested for fencing in Manang. Fences are both homogenous as well as heterogeneous types in Manang but heterogeneous fencing is most commonly seen surrounding crop fields. All cultivated lands are surrounded by fence to prevent entry of cattle (horse, goat, yak, mule etc).

Fuelwood in Manang is used for cooking and warmth. The main supply of fuelwood is from Betula utilis, Juniperus indica and Pinus wallichiana. Sometimes in absence of these plants other plants Abies spectabilis, Juniperus communis, Juniperus squamata, Juglans regia, Rosa macrophylla, Rosa sericea, Salix wallichiana and Taxus wallichiana are also used as fuelwood. The most preferred plant species for fuelwood in Manang is Betula utilis. It is highly regarded because of its durability for longer period (this means that it burns for long time) and with good burn. Similarly Juniperus indica is ranked second in the category of fuelwood because it is used extensively in Manang (Bhattarai et al., 2006b). The third ranked fuelwod is Pinus wallichiana.

Usually one person can collect fuelwood three times in 'Doko' (one 'Doko' contain ca. 40-50 kg of fuelwood) or traditional basket carried on the back, at a time a day from the nearest forest. For the two most remote areas of the district Nar and Phoo, this presents a great problem, as these regions are geographically isolated and lie above timberline. It is difficult for people to walk so far and carry an entire year's worth of fuelwood one load at a time, so in Nar and Phoo the dung of goats, yaks, mules and horses is used as fuel. Rosa sericea, Rosa macrophylla, Juniperus communis, and Juniperus squamata are also used as fuelwood at the time of scarcity of other fuel sources.

The use of insufficiently ventilated stoves burning smoky biofuels such as wood and animal dung has been found to have a negative impact on respiratory health. Melsom et al., (2001) found that the risk of asthma in Nepalese children was 2.2 times higher when they were exposed to the indoor use of smoky fuels than those not (odds ratio adjusted for cattle kept inside the house, tobacco smoke, and poultry) (Melsom et al., 2001). In India it was found that people exposed to this smoky fuel were at increased the risk of developing tuberculosis (Mishra et al., 1999), and in Spain a study has shown a strong association between exposure to wood smoke chronic obstructive pulmonary disease (COPD) (Orozco-Levi et al., 2006). Well ventilated stoves, or a switch to gas stoves, could improve health and prevent deforestation, but first the cultural importance of fuelwood should be addressed.

Several species of fuelwood have great cultural importance in Manang. Betula utilis and Juniperus indica fuelwood are also used in ritual and religious works. When people of Manang die, this wood is used to cremate the body. Huge amounts of fuelwood from Betula utilis, Juniperus indica and Pinus wallichiana can be seen stored on house and hotel rooftops in Manang district for the month of NovemberApril. These months are snowy and people cannot collect fuelwood due to snow. Fuelwood is culturally important as well as a renewable source of fuel that can have (potentially) an uninterrupted supply during the winter, unlike kerosene or biogas which depends on transport and can be limited in times of civil unrest, bad weather, or insufficient funds. May want to talk briefly about the fact that wood had been used for fuel in a sustainable manner for many generations, but now with increased population, increased number of migrant workers (collecting medicinal plants etc) and increased number of tourist/trekkers, the use of fuelwood harvested in the same manner is not sustainable.

The local people of TankiManang, Manang, Braka, Munji do not collect fuelwood, and furniture wood from their nearby 
forest these days as they did in the past and now collect from the next village (Hongde and Pisang forest). These forests (Hongde and Pisang forest) are big in comparison to their nearby forest now named as a 'community forest'. This is a good example of awareness towards conservation and management of the forest.

On the other hand, it is very interesting to note that although being the remotest district and geographically isolated we can also see the gas cylinder, and kerosene stove as an alternate source of fuelwood in Manang. There is in needs of more awareness among the people about forest needs and its role in the environment. This awareness programmes should be strengthened by the District forest office, Annapurna conservation Area Project and other NGOs of Manang which will be a first step towards the long term conservation.

\section{ACKNOWLEDGEMENTS}

The authors (SB and RPC) are thankful to NUFU, Norway and Volkswagen foundation, Germany for providing financial support for field work. We are grateful to the people of the Manang district of Nepal for their valuable ethnobotanical information and to the Annapurna Conservation Area project (ACAP) for research permission for the field work.

\section{REFERENCES}

Bhandari, H.R., and Shrestha, P. 1982. Ethnobotanical approach on the poisonous plants of Annapurna and Langtang Himal. Journal of Natural History Museum, 6 (4): 125-135.

Bhattarai, S., and Chaudhary, R.P. 2006. Ethnobotany of Wild Allium species in Manang District, Central Nepal. Plant Archives, 6 (2): 471-476.

Bhattarai, S., Chaudhary, R.P., and Taylor, R.S.L. 2006 a. Ethnomedicinal plants used by the people of Manang district, Central Nepal. Journal of Ethnobiology and Ethnomedicine, 2:41.

Bhattarai, S., Chaudhary, R.P., and Taylor, R.S.L. 2006b. Ethnobotany of wild Junipers (Juniperus species) in Manang district, central Nepal. Scientific world. 4 (4): 109-112.

Chaudhary, R.P. 1998. Biodiversity in Nepal: status and conservation. S. Devi, Shanpur (U.P.), India and Tecpress books Bangkok, Thailand.

Chhetri, R.B. 2005. Ethnobotany of bio-fencing in Dhulikhel region in Nepal. Ethnobotany, 17: 176-178.

Grierson, A.J.C., and Long, D.G. 1983-2000. Flora of Bhutan. Vol. I \& II. Part. I-III. Royal Botanic Garden, Edinburgh and Royal Government of Bhutan.

Hara, H., and Williams, L.H.J., 1979. An Enumeration of the Flowering Plants of Nepal. Volume II. British Museum of Natural History, London.
Hara, H., Charter, A.O. and Williams, L.H.J. 1982. An Enumeration of the Flowering plants of Nepal.Volume III. British Museum of Natural History, London.

Hara, H., Stearn, W.T., and Williams, L.H.J. 1978. An Enumeration of the Flowering Plants of Nepal. Volume British Museum of Natural History, London.

HMG/N. 1982. Wild edible Plants of Nepal. Ministry of Forests and Soil Conservation, Department of Medicinal Plants, Bulletin of the Department of Medicinal Plants No. 9, Kathmandu.

Manandhar, N. P. 1987. An Ethnobotanical profile of Manang Valley, Nepal. J. Econ. Tax. Bot., 10: 207-213.

Manandhar, N. P. 1989. Useful Wild Plants of Nepal. FranzSteiner Verlag Weisbaden GMBH, Stuttgart,Germany.

Manandhar, N. P. 2002. Plants and People of Nepal. Timber Press, Inc., Portland, Oregon, U.S.A.

Melsom, T., Brinch, L., Hessen, J.O., Schei, M.A., Kolstrup, N., Jacobsen, B.K., Svanes, C., and Pandey, M.R. 2001. Asthma and indoor environment in Nepal. Thorax, 56(6): 477-81.

Mishra, V.K., Retherford, R.D., Smith, K.R. 1999. Biomass cooking fuels and prevalence of tuberculosis in India. International Journal of Infectious Diseases, 3(3): 119-29.

Mueller-Boker, U. 1999. The Chitawan Tharus in Southern Nepal: An Ethnoecological Approach. Nepal Research Center Publication. No. 21. Franz Steiner Verlag, Stuttgart, Germany. pp. 224.

Orozco-Levi, M., Garcia-Aymerich, J., Villar, J., Ramirez-Sarmiento, A., Anto, J.M., Gea, J. 2006. Wood smoke exposure and risk of chronic obstructive pulmonary disease. European Respiratory Journal, 27(3): 542-6.

Pohle, P. 1990. Useful Plants of Manang District: A contribution to the Ethnobotany of the Nepal-Himalaya. Franz Steiner Verlag Wiesbaden GMBH, Stuttgart.

Polunin, O., and Stainton, A. 1984. Flowers of the Himalaya. Oxford Press, New Delhi, India.

Press, J. R., Shrestha, K. K. and Sutton, D. A. 2000. Annotated Checklist of the flowering Plants of Nepal. Natural History Museum, London and Central Department of Botany, Tribhuvan University, Kathmandu.

Rogers, C. 2004. Secrets of Manang: The story behind the phenomenal rise of Nepal's famed business community. Mandala Publications, Kantipath, Kathmandu, Nepal.

Spengen, V.W. 1987. The Nyeshangba of Manang: Geographical perspectives on the rise of Nepalese trading Community. Kailash, 13: $131-278$.

Stainton, A. 1988. Flowers of the Himalayas-A Supplement. Oxford University Press, New Delhi, India.

Toba, S. 1975. Plant names in Khaling: A Study in Ethnobotany and Village Economy. Kailash, 3(2): 145-169. 